\title{
9. Dignity- and reciprocity-based solidarity as the normative framework of the EU's constitutional settlement
}

\section{Sacha Garben}

\section{INTRODUCTORY REMARKS}

While being careful not to overstate the nature and degree of the EU's current problems, it seems fair to say that we are facing an increasingly volatile, tense and complex social-political situation in Europe. Eurosceptic and Eurocritical political movements seem to be on the rise, culminating (so far) in the UK's secession from the Union. ${ }^{1}$ There is a sense that, following a time in which Eurosceptics' concerns were mostly directed at perceived EU 'over-regulation' and generally came from a limited group of Member States, they are now increasingly phrased in broader socio-economic terms appealing to citizens that may feel 'left behind' or wronged by globalisation and Europeanisation processes, ${ }^{2}$ sometimes even where they receive extensive benefits through EU funds or financial assistance. ${ }^{3}$ These citizens tend to be wary of migration coming from both outside and within the EU. This plays into an east-west divide between 'old' and 'new' Member States, whereby the former are, first, suspicious of the internal labour mobility that for the latter is an intrinsic and important part of their political and constitutional settlement in the EU, ${ }^{4}$ and,

\footnotetext{
1 John FitzGibbon, Benjamin Leruth and Nick Startin (eds), Euroscepticism as a Transnational and Pan-European Phenomenon: The Emergence of a New Sphere of Opposition (Routledge 2017).

2 Theresa Kuhn et al, 'An ever wider gap in an ever closer union: rising inequalities and euroscepticism in 12 West European democracies, 1975-2009' (2016) 14(1) Socio-economic Review 27. See also Fotis Vergis, ch 8 in this volume.

3 Jones, Moya, 'Wales and the Brexit vote' (2017) French Journal of British Studies XXII-2.

4 Maurizio Ferrera, 'The contentious politics of hospitality: intra-EU mobility and social rights' (2016) 22(6) European Law Journal 79. See also Antonio Lo Faro, ch 2 in this Volume.
} 
second, resentful about the latter's lack of cooperation in the intake of migrants from outside the EU. Furthermore, a north-south divide has opened up following the economic crisis, whereby both creditor and debtor states somehow feel short-changed by the euro crisis measures taken, directing their discontent both at each other and at the EU. ${ }^{5}$ This latter conflict flared up again more recently in the context of the COVID-19 pandemic. ${ }^{6}$ Initially, certain southern Member States were particularly gravely affected by the pandemic, and they considered it a litmus test for the EU and its capacity to act in financial solidarity in the face of disaster as well as in the collective economic interest, while certain northern Member States were again reluctant to shift away from a conditionality-based approach to what they consider an undesirable 'transfer Union'. Arguably, only once it became fully clear that all Member States (like virtually all countries around the world) would be similarly gravely affected did it become possible to move on the development of ambitious common solutions, with, most notably, NextGenerationEU as a result.

The EU's various concrete and abstract regulatory challenges and aims have regularly been considered from the perspective of solidarity and competition, ${ }^{7}$ which are recurrent themes in the study of federal orders more generally, alongside the notion of cooperation. ${ }^{8}$ An analysis by reference to these notions allows an exploration of the duties that the various actors in multi-level orders can be said to hold toward the common federal project and one another, and

5 Donatella Della Porta, Hara Kouki and Joseba Fernández, 'Left's love and hate for Europe: Syriza, Podemos and critical visions of Europe during the crisis' in Manuela Caiani and Simona Guerra (eds), Euroscepticism, Democracy and the Media (Palgrave 2017); Sara B. Hobolt and Catherine de Vries, 'Turning against the Union? The impact of the crisis on the Eurosceptic vote in the 2014 European Parliament elections' (2016) 44 Electoral Studies 504.

6 Charlotte Beaucillon, 'European Solidarity in Times of Emergency: An Introduction to the Special Focus on COVID-19 and the EU' (2020) European Papers, www.europeanpapers.eu/en/europeanforum/european-solidarity-in-times-of -emergency-introduction-special-focus-covid-19\#_ftn2 accessed 11 June 2021.

7 Paolo Chiocchetti and Frédéric Allemand, $\bar{C}$ ompetitiveness and Solidarity in the European Union: Interdisciplinary Perspectives (Routledge 2019). See also in particular the work of Wolfgang Streeck: 'International competition, supranational integration, national solidarity - the emerging constitution of "Social Europe" in Martin Kohll and Mojca Novak (eds), Will Europe Work? Integration, Employment and the Social Order (Routledge 2001); Wolfgang Streeck, 'Competitive solidarity: Rethinking the European Social Model' in Karl Hinrichs et al (eds), Kontingenz und Krise (Campus Verlag 2000).

8 See Ronald L. Watts, 'Origins of cooperative and competitive federalism' in Scott L. Greer (ed) Territory, Democracy and Justice (Palgrave Macmillan 2006); Ingwer Ebsen, 'Social policy in the European Community between competition, solidarity and harmonization: still on the way from a free trade area to a federal system' (1995-6) 2 Columbia Journal of European Law 421. 
of the centrifugal and centripetal dynamics that may result from the way these notions are operationalised in a given situation. They can serve both descriptive and normative functions: considering how the EU currently functions by reference to these concepts, and considering how it should. Jacques Delors expressed the idea of a union with 'competition that stimulates, cooperation that strengthens, solidarity that unites'. 9 This contribution analyses these concepts and their interaction, adding dignity as a fourth crucial piece to the puzzle, in order to act as a pre-condition, condition and guide for these other notions. ${ }^{10}$ It will argue that even if the core values of solidarity and dignity have become part of the EU's constitutional foundation, at present they are insufficiently conceptualised and operationalised in the European integration process, which remains dominated by a focus on competition. The contribution aims to provide some reflections that may aid in the establishment of a theoretical framework; this could translate more concretely into an alternative narrative to both support and condition the European integration process, to be in turn implemented and applied in specific instances of EU law and policy, both through (transnational) competition and cooperation.

\section{THE NOTIONS OF SOLIDARITY, DIGNITY, COMPETITION AND COOPERATION AND THEIR INTERACTION}

This section addresses the question: How are the concepts of solidarity and dignity, and competition and cooperation, to be understood and how do they interact, taking into account both an individual and a collective as well as a national and a transnational dimension? While this contribution in no way seeks to provide an exhaustive discussion of the matter, it will nevertheless be necessary to establish some fundamental understanding of these terms and their interrelation, before applying them in the rest of the chapter.

\footnotetext{
9 By reference to the Single European Act. Jacques Delors, Mémoires (Plon 2004) 326.

10 This is but one analytical framework or set of concepts that can anchor an assessment of the various regulatory challenges and (dis)integrative dynamics in a multi-level order like the EU, and it is not this chapter's contention that it is the best or only one. As the assessment in this chapter reveals, however, this alternative to the more commonly used prisms of, for instance, the Rule of Law, democracy, legitimacy, subsidiarity or effectiveness manages to tease out some different insights.
} 


\subsection{Solidarity}

On a theoretical level, there is a question regarding how solidarity is distinct from related 'other-regarding dispositions' that involve a measure of generosity, in that someone deliberately performs an action that is sub-optimal for him but for the benefit of another, such as altruism, sophisticated selfishness, team reasoning and Kantian duty. It could be argued that while solidarity may very well co-exist with them, it motivates generosity independently (thus, even in the absence) of these other-regarding motivations, on the basis of 'an identification with the condition of a certain group of people' to whom one does not (directly) belong. ${ }^{11}$ It would therefore be a self-standing notion. However, the lack of team spirit as motivation for the generous action in this narrow approach seems to be at odds with a more colloquial understanding of the term, in which it is for instance associated with collective action undertaken by workers against an employer, where team reasoning is likely to play a key part. ${ }^{12}$ Indeed, the usefulness of the concept of solidarity to understand the functioning of (transnational) societies would be drastically limited if such a narrow definition were followed. Manifestations of genuine out-of-group non-reciprocal solidarity are very rare. ${ }^{13}$

For the purposes of this chapter, it does not seem necessary to take such a strict approach to solidarity that excludes the conceptual forms of 'other-regarding generosity' which somehow rely on team or group membership. Instead, the notion will be used more pragmatically, and its key features will be taken to lie in a certain act being performed deliberately that is (perceived as) sub-optimal for the actor(s) at least in the short term, for the benefit of (an)other(s), which may be members of the same group or not. This includes actions that are expected to yield benefits for the actor(s) in the longer term, with the exception of guaranteed overall net benefits (which would simply make the action a rational investment). It shall be taken as a gradual concept, in that something can reflect weaker or stronger solidarity. Thus, the smaller the role of reciprocity or expected returns, the higher the level of solidarity, but the fact that reciprocity or returns are expected does not eliminate solidarity as such.

11 Christian Arnsperger and Yanis Varoufakis, 'Toward a theory of solidarity' (2003) 59(2) Erkenntnis 157.

12 Robert Sugden 'Thinking as a team: towards an explanation of nonselfish behavior' (1993) 10(1) Social Philosophy and Policy 69.

13 One could think of, for example, the provision of humanitarian assistance to another group (country) in the case of a natural disaster, when it is provided without any reasonable expectation of receiving such assistance when disaster strikes the assisting group (country) at a later point. 
This wider approach better corresponds to the conception of solidarity in the EU as defined by Sangiovanni in his landmark piece on the subject. ${ }^{14}$ He understands demands for social solidarity at all levels of governance as 'demands for a fair return in the mutual production of important collective goods' ${ }^{15}$ The idea is that in our societies 'we depend on the joint contributions of myriad other citizens and residents for the ability not only to develop but also to act on a plan of life'. ${ }^{16}$ As our abilities to develop, use and profit from our talents depend on the survival and maintenance of the scheme, those who are better able to gain from the scheme owe those less able, but who have made their gains possible, a fair return for what they have received. ${ }^{17}$

This is clearly a reciprocity-based framework and includes team reasoning as an important basis for solidarity. I would argue that both (i) participation in the survival and maintenance of the scheme of which one is not certain whether it will be to one's immediate benefit, in addition to the expected common benefit, as well as (ii) a measure of redistribution of the actual benefits yielded by it from the 'winners' to the 'losers', are - within this conception - to be qualified as acts of solidarity. Such solidarity can be expected to be stronger when the common (societal) scheme is more developed and visible, and when participants feel more strongly attached to the identity of the underlying group, that is, the 'team'. That clearly implies some challenges for the existence of such solidarity in a context that transcends one's primary community, which in the EU context is generally still the national level. ${ }^{18}$ Nevertheless, the fact that there are challenges does not mean that such solidarity cannot be present in a transnational setting such as the EU as well. ${ }^{19}$ It has already been shown that identity can, and in a majority of cases does, exist at several levels, including the national and EU levels. ${ }^{20}$ And, while it may be less developed and visible to citizens, it is clear that the EU provides a kind of common societal scheme from which all Member States are expected to benefit in the long run.

14 Andrea Sangiovanni, 'Solidarity in the European Union' (2013) 33(2) Oxford Journal of Legal Studies 213.

15 ibid, 217.

16 ibid.

17 ibid, 222.

18 Thomas Risse, A Community of Europeans? Transnational Identities and Public Spheres (Cornell University Press 2010).

19 Carol C. Gould, 'Transnational solidarities' (2007) 38(1) Journal of Social Philosophy 148.

20 Risse (n 18). 


\subsection{Dignity}

Dignity, or human dignity, is an existential value that is often considered as the very source of all human rights and an overarching constitutional principle. In general terms it can be understood as the right of any person to be valued and respected for their own sake, and to have a degree of autonomy and agency in life (and, as is increasingly argued, as regards death). While certain theoretical approaches to dignity emphasise that dignity is achieved through (moral) actions, in legal terms dignity seems more often to be defined as the right to be respected (precisely) regardless of one's actions: everyone is equal in dignity (Article 1 UDHR). There are many different requirements of dignity in different contexts. People's physical integrity and protection against inhumane and degrading treatment are of course central to the protection of dignity. But also the right to participate in collective decision-making in society, and thus a right to democratic participation, could be considered an important requirement of the agency that dignity necessitates. ${ }^{21}$ Furthermore, socio-economic conditions are salient: poverty, social exclusion and labour exploitation are important violations, while 'meaningful work is considered essential for dignity'. ${ }^{22}$

There is a complex interaction between dignity and solidarity. Solidarity can be conducive of dignity and an instrument to achieve it, such as through camaraderie and solidarity with coworkers ${ }^{23}$ or through a welfare system preventing social exclusion. At a more fundamental level, solidarity could be considered to be the psychological source of the right to dignity, as it results from the collective identification of all humans as a single group. ${ }^{24}$ Yet, counter-intuitively, expressions of solidarity can also challenge dignity. To the extent that the sub-optimal action of the person engaging in an act of solidarity for the benefit of another creates a (perceived) debt in the recipient, this may challenge their sense of self-worth, agency and autonomy, all of which are important components of dignity. A solidaristic welfare system that is not dignity-based might on the one hand seem to combat social exclusion and poverty through redistributive benefits, but could at the same time treat the recipients of such benefits in such a way that they are shamed to a degree that infringes their dignity all the same. Conversely, (the requirements of) dignity may also challenge solidarity in certain situations. To the extent that dignity demands (actions reinforcing the) respect of a person regardless of their 
actions, it may benefit individuals who can be seen as having acted contrary to the collective good of society and who are therefore, in a reciprocity-sense, 'undeserving'. For some, this may erode the very trust that the system will reward good behaviour and punish bad behaviour which could be argued to underlie solidarity within society more generally.

Dignity is inherent in every individual. Whether it is also a right that can be claimed for a group is debatable, and ties in with the general controversy on individual and collective rights. Whether or not explicitly conceptualised as group rights, many human rights work at both levels. For instance, the right not to be discriminated against on the basis of race, ethnic origin, religion or belief is a right conducive to dignity held by an individual, but informed by a sense of collective identity and collective self-worth, where an attack on another member of the group can be felt as an infringement of the rights of all members of the group. For the purposes of this chapter, it would seem useful to conceptualise dignity both individually and collectively. Within the specific EU context, it is furthermore interesting to consider whether Member States as such may be argued to have a claim to dignity. The prohibition of discrimination on grounds of nationality would be the translation thereof on the individual level, and the protection of national constitutional identity (Article 4(2) TEU) could be seen as a legal recognition of their dignity as independent states.

\subsection{Competition}

In a colloquial sense, competition refers to the activity or condition of striving to gain or win something by defeating or establishing superiority over others. This 'something to be won' can be a resource in limited supply, but also something more intangible, such as prestige. Competition has many different manifestations. It can be a default state of affairs, where a certain good in scarce supply is pursued by a variety of actors in the absence of a regulatory framework, or instead a deliberate method to distribute a certain good among various actors on the basis of pre-defined criteria. In the latter sense, it can be used as a deliberate governance tool - as it is in most market economies. When competition leads to the attribution of a certain good, it is often considered 'fair' when this happens in compliance with the (implicitly) agreed criteria of the competition, for instance when a company is successful on the market because it has developed an original, high-quality product. In contrast, such a result is considered 'unfair' when the implicit or explicit (social) rules framing the competition are not respected, such as when the company is successful on the market because it can operate low prices due to its products being produced by children in sweatshops. This illustrates the important normative dimension of the context in which the notion of competition operates, and while it is 
sometimes juxtaposed with regulation, it actually often has a close, dependent relationship with it.

The foregoing examples show the tension that exists between competition on the one hand and solidarity on the other. They can both be conceived as frameworks for the allocation of goods and the structuring of behaviour in society, but using very different methods and on the basis of different goals and values. However, it would be too simplistic to exclusively use them in opposition or mutual exclusion, as there is more nuanced conceptual interaction between the two. For one, competition can be a governance tool used for the pursuit of solidarity objectives. In the EU, for instance, the Social Open Method of Coordination places Member States in a comparative setting, competing for the best social performance (thus for prestige in an international context and for the best policy outcomes in a national context), which encourages them to improve their national solidarity policies. More generally, policy competition such as that between constituent jurisdictions in federations allows for policy experimentation, which may yield important social benefits by developing best practices at the lowest risk/cost for the overall federation. ${ }^{25}$ In a different mutually reinforcing way, solidarity structures can make economies more resilient and stable, and as such more competitive in the long run. Competition can, to a certain extent, also be an expression of solidarity - when it constitutes the common system which is in the end expected to deliver common goods, but which does not guarantee immediate net benefits to all participants (for instance, participation in the internal market, where high-wage Member States may expect to lose some industry to lower-wage states). And, to constitute an overall successful governance tool, competition may require being complemented by a degree of solidarity, for instance in the redistribution of the yields of the common system of competition from the 'winners' to the 'losers'.

When it comes to dignity, in turn, it would seem that the very fact of creating winners and losers means that competition represents a certain challenge to dignity. Dignity tends to become part of the competition itself: the winner gains an increase in self-worth where the loser precisely gives it up. ${ }^{26}$ Even where the competition can be considered 'fair', the mere fact of losing creates a certain tension with the confidence that is an important component of dignity. Where competition is accompanied by solidarity to mitigate the negative consequences of losing, it is important that such action does not

25 Daniel Halberstam, 'Federalism: a critical guide' (2011) University of Michigan Public Law Working Paper No. 251, 16, https://papers.ssrn.com/sol3/papers.cfm ?abstract_id=1924939\#\#, accessed 14 June 2021.

26 Robert J. Vallerand, Lise I. Gauvin and Lise W. Halliwell, 'Effects of zero-sum competition on children's intrinsic motivation and perceived competence' (1986) 126(4) The Journal of Social Psychology 465. 
somehow reinforce the degree of humiliation connected to losing. Of course, it could be argued that the negative effect on dignity created by losing can very well be overcome depending on the context, and that it may spur the individual or group into action, motivating them to improve themselves. Such self-development, and the possibility of subsequent wins, could be argued to be conducive to dignity, as well as valuable for society overall (through, for example, increased productivity). It would thus appear that competition does not have to be a zero-sum game, but that there are both malign and benign competitive processes, depending on the specific circumstances.

\subsection{Cooperation}

A final word on the notion of 'cooperation', understood as the action or process of working together towards the same end, which seems often to be used in contrast to competition and more closely aligned to solidarity. It is true that cooperation can be an alternative to competition, for instance when the default state of competition to obtain a scarce good is replaced by a system of cooperation to obtain (and share) that good. Depending entirely on the context, replacing competition with cooperation may be considered societally desirable, such as when countries cooperate for the advancement of technology rather than competing in isolation, or societally undesirable, such as when companies agree on setting common prices eliminating competition between them and overcharging the consumer. In other scenarios, however, competition and cooperation are not opposing alternatives and can work together. Competition can be a precondition to, a form of, or an incentive for cooperation, and vice versa. ${ }^{27}$ For instance, opening up one's markets to economic competition will usually lead to the establishment of some form of common regulatory framework with minimum rules of labour and environmental protection. Indeed, the expectation that economic integration through competition will lead to functional spill-over in the form of cooperation in many policy areas has often been mentioned as one of the main drivers of European integration.

Cooperation and solidarity are often regarded as having a mutually beneficial interaction, and they can indeed be conceived as going hand in hand in many situations, such as where workers collaborate through collective action to improve each other's working conditions (which, as mentioned above, are also ways to achieve dignity), or where Member States cooperate on a common policy for the protection of a certain public interest. Cooperation can thus be an expression of solidarity, and solidarity an outcome of cooperation.

27 Peter Abell, 'A model of the informal structure (culture) of organizations: help, trust, rivalry and team spirit' (1996) 8(4) Rationality and Society 433. 
Furthermore, it would seem that cooperation is more effective when there is a measure of solidarity among the participants, so as to avoid free-riding behaviour. ${ }^{28}$ Nevertheless, cooperation can sometimes also have the result of challenging solidarity, especially in multi-level/transnational contexts such as the EU. Member States can cooperate to establish certain common policies which undermine solidarity structures on the national level, ${ }^{29}$ such as the freedom to provide services which allows companies to undercut certain domestic social standards in certain situations. They can also cooperate to demand a measure of transnational solidarity, for instance to extend national social benefits to migrant EU citizens, which may challenge national solidarity by expanding the group beyond the necessary level of identification and expected reciprocity (and as such lead to a lowering of social benefits for all).

It could be posited that genuine cooperation, also in a transnational setting, requires the participation of everyone involved and affected. In that way cooperation would be profoundly conducive to dignity, by ensuring agency and empowerment. If, on the other hand, transnational decisions are taken without genuine input from the individuals/collectives affected by the decisions, through undemocratic procedures, this risks violating the individual and collective dignity of the subjects by denying them the necessary agency and power to decide on crucial elements of their daily lives. An argument could be made that some issues, such as a certain measure of transnational solidarity, have to be imposed and enforced regardless of the majority preferences of a given sub-group, in the interest of the overall collective. Yet the risks that this implies, not just for democracy but also for dignity, need to be recognised. Such exclusion is furthermore unlikely to benefit the identification of the individual with the overall collective and the policies that govern it, and thus it could be posited that undemocratically imposed solidarity undermines genuine solidarity in the long run.

\subsection{Interim Conclusions: Multifaceted Interactions}

The foregoing brief discussion on the concepts of dignity and solidarity, and competition and cooperation, have revealed a multitude of possible interactions. These interactions are multi-directional and more complex than perhaps expected at face value. For one, while dignity and solidarity may often be

28 Arnsperger and Varoufakis (n 11); Wolfgang Weidlich and Dirk Helbing, 'A mathematical model of group dynamics including the effects of solidarity' in Patrick Doreian and Thomas Fararo (eds) The Problem of Solidarity: Theories and Models (Routledge 1998).

29 See the example of Sweden and its model for labour market regulations in Caroline Johannsson, ch 5 in this volume. 
considered natural normative 'allies', there is a pronounced risk that solidarity actions may actually challenge dignity and vice versa. This is an insight that should arguably inform redistributive welfare policy both at national and transnational level. On the other hand, while competition and solidarity are often considered at odds with each other, it appears that there are also scenarios where they interact more fruitfully; indeed, participating in the competition inherent in an internal market can be conceptualised as an act of solidarity and the cooperation that preconditions and results from it may furthermore strengthen the team identification that feeds solidarity. That insight is important to counterbalance the idea that market processes are inherently centrifugal, creating inequalities and losers that will destabilise the 'group' and/or the overarching framework. However, a third insight is that such competitive processes, while not necessarily disruptive of solidarity, do often challenge dignity (both individual and collective). While cooperation, when it is genuinely inclusive, may constitute a desirable alternative to competition that better respects dignity and fosters solidarity, a fourth take-away is that undemocratic transnational cooperation can instead be expected to erode both solidarity and dignity in the long run. Finally, in a federal setting, these notions will reveal different dynamics depending on the respective governance level, between and even within themselves: for instance, transnational solidarity policies may undermine national solidarity structures (welfare tourism); transnational competition can strengthen national solidarity but challenge transnational solidarity; and so on.

\section{SOLIDARITY, DIGNITY, COMPETITION AND COOPERATION IN THE EU LEGAL ORDER}

This section will address the question: How are the concepts of solidarity and dignity, and competition and cooperation, operationalised through legal mechanisms in the EU?

\subsection{Legal Mechanisms to Ensure Solidarity}

Most federations feature a solidarity principle. According to Cyr,

[t]he principle of federal solidarity [...] creates certain positive duties of assistance, and certain prohibitions against imposing certain negative externalities on other federal partners. Cooperative federalism is thus normatively justified by the need for 
each level of government to protect and promote the interests of a shared citizenry forming a common body politic. ${ }^{30}$

This definition underlines the observation made in the previous section that a wide definition of solidarity encompasses both (i) the act of participating in a common system that does not guarantee immediate returns to each participant and (ii) the redistribution of the general benefits generated by that system by the 'winners' to the 'losers'. Cooperation in itself can thus be an expression of solidarity, in the sense that it presents a sub-optimal action for the actor in the short term for the benefit of the collective project. To the extent that the success of the collective project depends on this minimum measure of cooperation, it could be considered a requirement under a legal solidarity principle.

The EU legal order does not know, in so many words, the principle of 'federal solidarity' or 'federal comity' as it is present, for instance, in German constitutional law. ${ }^{31}$ Nevertheless, the Treaties do lay down the principle of sincere cooperation in Article 4(3) TEU. While this may first and foremost refer to the duties of the Member States and the EU institutions vis-à-vis each other, the principle also has an important horizontal dimension, ${ }^{32}$ which could be explored more fully if one is to boost the EU's problem-solving capacity as well as Member State solidarity. The duty of sincere cooperation has not often been invoked in this context, but it would seem that it could be used whenever Member States are facing an essentially common problem (like an influx of third country migration ${ }^{33}$ ), where the negative consequences fall more heavily on a single state or a limited group of states to the potential 'benefit' of other states, in order to impose a duty on the 'free-riding' Member States to constructively seek a solution.

Indeed, such a positive duty of cooperation in terms of Member State solidarity has been further specified in a number of areas, most explicitly in the AFSJ. Article 67(2) TFEU provides that the Union shall 'frame a common

30 Hugo Cyr, 'Autonomy, subsidiarity, solidarity: foundations of cooperative federalism’ (2014) 23(4) Constitutional Forum 20.

31 Hans-Peter Schneider, 'German unification and the federal system: the challenge of reform' in Charlie Jeffery (ed), Recasting German Federalism: Legacies of Unification (Pinter 1999).

32 Marc Blanquet, L'article 5 du Traité CEE: recherche sur les obligations de fidélité des États membres de la Communauté (LGDJ 1994); Marcus Klamert, The Principle of Loyalty in EU Law (OUP 2014); Christoph Vedder, 'Art. I-5', in Christoph Vedder and Wolff Heintschel von Heinegg (eds), Europäischer Verfassungsvertrag. Handkommentar (Nomos 2007).

33 Pierre Vimont, Migration in Europe: Bridging the Solidarity Gap (Carnegie Endowment for International Peace 2016), http://carnegieendowment.org/files/Vimont _Migration_fulltext.pdf, accessed 14 June 2021. 
policy on asylum, immigration and external border control, based on solidarity between Member States, which is fair towards third-country nationals'. Article 80 TFEU reiterates that this policy 'shall be governed by the principle of solidarity and fair sharing of responsibility, including its financial implications, between the Member States' and indicates that Union acts adopted in this area 'shall contain appropriate measures to give effect to this principle'. The obstructive behaviour of some Member States in the context of the migration crisis has infringed this duty of solidarity and has highlighted the risk of free-riding. The European Commission has referred Poland, Hungary and Czechia to the CJEU for refusing to comply with their obligations under the provisional emergency relocation scheme (Council Decision (EU) 2015/1523 and Council Decision (EU) 2015/1601). ${ }^{34}$ The CJEU had already rejected the challenges against the relocation system brought by Hungary and Slovakia, stressing the solidarity obligation that rests on the Member States in this area on the basis of Article 80 TFEU, ${ }^{35}$ and has now also upheld the Commission's action, making multiple references to the principle of solidarity underlying the Union's asylum policy. ${ }^{36}$

A second important context-specific reference to solidarity in the Treaties can be found in Article 122 TFEU. This is a rather different manifestation of the principle. On the one hand, it seems to call for a strong expression of solidarity, in that emergency assistance is provided without any expectation of benefits in return. On the other hand, if read in its context and particularly in conjunction with the no-bailout clause of Article 125 TFEU, the reciprocal nature of this provision becomes clear. The fact that this gives rise to a limited form of conditional solidarity could clearly be seen in the context of the euro crisis, where the initial financial assistance was granted on the basis of Article 122 TFEU. In Pringle, the CJEU held that this provision is concerned solely with ad hoc Union assistance to Member States and not inter-Member State assistance. ${ }^{37}$ The Court in that judgment also held that Article 125 TFEU prohibited the granting of financial assistance as a result of which the incentive of the recipient Member State to conduct a sound budgetary policy is diminished, but not where the recipient Member State remained responsible for its commitments to its creditors and the conditions attached to such assistance required a sound budgetary policy. This balanced interpretation of Article 125 TFEU coincides

34 See Joxerramon Bengoetxea, ch 7 in this volume.

35 Joined Cases C-643/15 and C-647/15, Slovak Republic and Hungary $v$ Council of the European Union, ECLI:EU:C:2017:631.

36 Joined Cases C-715/17, C-718/17 and C-719/17, European Commission v Republic of Poland and Others, ECLI:EU:C:2020:257.

37 Case C-370/12, Thomas Pringle v Government of Ireland and Others, ECLI:EU: C:2012:756. 
with the one proposed by the Advocate General, who had come to this solution by reasoning on the explicit basis of the principle of solidarity. The Advocate General opined that from the various iterations of solidarity in the Treaty it could not be inferred that there existed a duty to provide financial assistance, but did support a reading of Article 125 TFEU allowing for voluntary assistance. ${ }^{38}$ The Advocate General qualified the principle of solidarity between Member States as a 'basic fundamental principle of the Treaties'.

Third, in recognition of the socially disruptive effects of the internal market (see also section 3.2), the EU Treaties feature redistributive mechanisms, such as the European Social Fund (Article 162 TFEU). More generally, Article 174 TFEU provides that 'to promote its overall harmonious development, the Union shall develop and pursue its actions leading to the strengthening of its economic, social and territorial cohesion'. These objectives are mainly pursued through the European Structural and Investment Funds, which had an overall budget of 454 billion euro for the period 2014-20. In addition, a separate Fund for European Aid to the Most Deprived disposed of 3.8 billion euro for the 2014-20 period to provide material assistance to the most deprived in the form of food, clothing and other essential personal items. Such redistributive measures can clearly be seen as an expression of federal solidarity ${ }^{39}$ and of the kind of reciprocity-based redistributive solidarity postulated by Sangiovanni.

\subsection{Legal Mechanisms to Ensure Competition}

It is hard to imagine a federation that does not somehow guarantee the mobility of its citizens and companies, and their products and services, throughout the federal territory. This certainly does not have to be an unconditional mobility, but a baseline right to establish oneself freely in any of the constituent members and to pursue economic activities there seems to exist in virtually all federal systems. The way in which, and the degree to which, this mobility is ensured is highly relevant for the purposes of our discussion. In general terms, it would seem that the more extensive the mobility rights, the more liable the system is to produce competition, and the more difficult it becomes to maintain or produce national solidarity outcomes.

\footnotetext{
38 ibid, Opinion of AG Kokott.

39 Andreas Follesdal, 'Justice, stability and toleration in a federation of well-ordered peoples' in Martin Rex and David A. Reidy (eds), Rawls's Law of Peoples: A Realistic Utopia? (Wiley 2006).
} 
This first and foremost applies to the mobility rights of companies, which are generally considered to be more mobile than individual citizens. In Halberstam's words:

as soon as the incidents of regulation fall heavily on one entity, say a manufacturer (and its workers), while the benefits fall on another or on citizens more generally, [mobility of the objects of regulation] limits the exercise of public power. This is why, for example, redistributive policies are difficult to maintain at the level of local government, as the United States Supreme Court recognized in upholding federal unemployment laws. ${ }^{40}$

In the EU context, the free movement provisions have been broadly interpreted by the CJEU to include an element of market access in addition to a non-discrimination requirement. In particular, the power of the freedom of establishment and of the freedom to provide services to overrule or undermine national solidarity mechanisms is, by now, well known. ${ }^{41}$ High-profile cases such as Centros, Viking and Laval have brought this to the attention of an audience much broader than the academic one, but there are many others. ${ }^{42}$ And, of course, this de-regulatory effect is not only measured by CJEU cases, as many such practices may simply go uncontested (and are in fact the very essence of these market freedoms) or dealt with in national courts.

However, even if companies are indeed more mobile, such negative pressure on national solidarity could also be considered to derive from mobility rights for individual citizens, albeit more indirectly. While the mobility rights of individual citizens, and thus their freedom to choose the most attractive mix of taxes, services and social benefits across the federal territory, could be portrayed as a social aspect of federalism (as it is often said to be in the context of the EU and the rights of non-economically active citizens), as it forces jurisdictions to extend a degree of solidarity to citizens of other jurisdictions, such mobility could also be hypothesised to lead to competition that undermines solidarity structures on the national level in the longer run. In Volden's words, the idea is that 'competition may lead to the undersupply of welfare benefits, through a "race to the bottom", with states cutting their benefits in response to their neighbours' cuts in order to avoid becoming "welfare magnets" whose

40 Daniel Hamberstam, 'Federalism: a critical guide' (2011) University of Michigan Public Law Working Paper No. 251, 19.

${ }^{41}$ Sacha Garben, "The constitutional (im)balance between "the Market" and "the Social" in the European Union' (2017) 13(1) European Constitutional Law Review 23.

42 Such as, for example, Case C-576/13, Commission v Spain [2016] EU:C:2014: 2430, Case C-201/15, AGET Iraklis, EU:C:2016:972. 
high payments attract potential recipients from surrounding states'. ${ }^{43}$ The requirement of transnational solidarity is thus liable to undermine national solidarity through the mechanisms of regulatory competition, especially where such national solidarity itself is not sufficiently robust.

In the EU, the CJEU has developed the principle of solidarity between the Member States in the context of the free movement of persons and specifically of EU citizenship. This has meant concretely that Member States cannot refuse access to, or deport, non-national EU citizens simply because they have committed a crime or are not contributing to the economy. Furthermore, the fact that a non-national EU citizen does not contribute to the economy may not necessarily imply that they are not entitled to rely on national solidarity mechanisms such as social benefits. The Court has held specifically that students are entitled to maintenance grants after fulfilling a certain prior-residence criterion $^{44}$ and that work-seekers have the right to employment-related benefits on equal terms to those of nationals. ${ }^{45}$ But, indeed, this requirement of solidarity has proven politically controversial. ${ }^{46}$ Concerns were raised in a number of Member States about 'welfare tourism', especially in the UK. EU scholars have thus pointed out the danger that such intra-European solidarity may well undermine national solidarity, ultimately lowering the level of social facilities for everyone. ${ }^{47}$ Perhaps in response to these concerns, the CJEU adjusted its stance in the much-debated Dano and Alimanovic cases. ${ }^{48}$

43 Craig Volden, 'The politics of competitive federalism: a race to the bottom in welfare benefits?' (2002) 46(2) American Journal of Political Science 352, 352.

44 Case C-209/03, The Queen, on the application of Dany Bidar v London Borough of Ealing and Secretary of State for Education and Skills, ECLI:EU:C:2005:169.

45 Joined cases C-22/08 and C-23/08, Athanasios Vatsouras (C-22/08) and Josif Koupatantze (C-23/08) v Arbeitsgemeinschaft (ARGE) Nürnberg 900, ECLI:EU:C: 2009:344.

46 For a recent post-Brexit discussion see Gareth Davies, Migrant Union citizens and social assistance: trying to be reasonable about self-sufficiency (2016) College of Europe Research Paper, www.coleurope.eu/sites/default/files/research-paper/ researchpaper_2_2016_davies.pdf, accessed 14 June 2021.

47 Kay Hailbronner, 'Union citizens and access to social benefits' (2005) 42 Common Market Law Review 1245; Augustín José Menéndez, 'European citizenship after Martinez Sala and Baumbast: has European Law become more human but less social?' in Miguel Poiares Maduro and Loïc Azoulai (eds), The Past and Future of EU Law: The Classics of EU Law Revisited on the 50th Anniversary of the Rome Treaty (Hart Publishing 2010).

48 Case C-333/13, Elisabeta Dano and Florin Dano v Jobcenter Leipzig, EU:C: 2014:2358; Case C-67/14, Jobcenter Berlin Neukölln v Nazifa Alimanovic and Others, EU:C:2015:597. 


\subsection{Legal Mechanisms to Ensure Dignity}

The most important legal mechanism to ensure dignity in any political order is the recognition and protection of fundamental human rights. The intrinsic connection between dignity and human rights becomes clear upon reading any human rights instrument, and it is regarded by many as the foundation of all human rights. ${ }^{49}$ It is relevant to recall the different dimensions of dignity discussed in section 1, namely those of physical integrity, of political/societal agency and of social inclusion. These different dimensions could be said to correspond to different types of human rights: the former two to civil and political rights; the latter to social and economic rights. In the EU, all these different rights are contained in the EU Charter of Fundamental Rights (hereinafter the Charter). Apart from being the first value mentioned in Article 2 TEU, the Charter enshrines human dignity in its very first article, ${ }^{50}$ and its first chapter (comprising furthermore the right to life, the right to the integrity of the person, the prohibition of torture and the prohibition of slavery and forced labour) is entitled 'Dignity'. The Charter is legally binding and has equal value to the Treaties.

In most federal systems, human rights are mainly protected at the central level. However, in the EU, the Charter applies primarily to the EU institutions and only to the Member States when they act in the scope of EU law. Whether this limitation of the EU's authority on fundamental rights comprises its capacity to effectively protect and enhance the dignity of its citizens and its sub-collectives is open to debate. On the one hand, all Member States are members of the ECHR and therefore subject to supranational human rights adjudication, and most Member States additionally feature robust human rights guarantees at the national constitutional level. It is in turn from the ECHR and national constitutional traditions that the CJEU derives its interpretation of fundamental rights at EU level, ${ }^{51}$ and it could be argued that all this leads to a multi-dimensional and multi-level protection of human dignity through human rights in Europe that is sufficiently effective without the need to further enhance the EU's role in that regard. Furthermore, some would argue that it is better to have the EU play a subsidiary role in this regard, as it would not be capable of legitimately fulfilling an internal role as a human rights actor. The main critique there is that the EU, perhaps due to its origins as a project of market-making and economic integration, does not have the necessary social

49 Willy Moka-Mubelo, 'Human rights and human dignity' in Willy Moka-Mubelo (ed), Reconciling Law and Morality in Human Rights Discourse (Spinger 2016).

50 'Human dignity is inviolable. It must be respected and protected.'

51 Article 52(3) CFREU provides that the meaning and scope of the rights that are also contained in the ECHR shall be the same as in the case of the latter. 
sensitivity to give the necessary protection to social rights, and that overall its integrative motto will lead to precedence being given to the effectiveness, autonomy and unity of EU law over a maximalist protection of human rights standards where these two clash. ${ }^{52}$ To the extent that this critique holds water, however, a concern is that in the relatively broad scope of situations that fall within EU law, the EU is the final authority on human rights and the way they interact with other provisions and obligations under EU law, and at times this had led to rulings that could be argued to raise some questions from a human rights and human dignity perspective, ${ }^{53}$ especially concerning fundamental social rights. ${ }^{54}$

\subsection{Interim Conclusion: An (Im)Balanced Operationalisation of Competition, Cooperation, Dignity and Solidarity in EU Law}

Looking at the various mechanisms of competition, cooperation and solidarity in the EU, it does seem fair to conclude that, on balance, those that serve to foster competition are stronger than those fostering solidarity (either on the national or the European level). The free movement provisions grant hard rights that can be enforced in national courts, for instance by economic operators who can thereby seek to maximise their mobility in order to choose the regulatory system of their preference and operate throughout the EU from there. Through the principle of mutual recognition, the need for cooperative action is diminished and regulatory competition can do its work. When the EU does take cooperative action in this area, it tends to be in order to replace existing national impediments that are justified restrictions to trade; while the outcome is usually a common 'full' norm which removes regulatory differences and hence reduces regulatory competition, this does actually enhance inter-company competition in the EU and reduces the power of the national level to decide on the public (including social) interest. Furthermore, the EU has legislated (cooperated) to open up public sectors to the market (for competition). In comparison, the EU's solidarity mechanisms are weak.

52 See for a discussion of this problématique in the area of asylum: Takis Tridimas, 'Competence, human rights, and asylum: what price mutual recognition?' in Sacha Garben and Inge Govaere (eds), The Division of Competences between the EU and the Member States (Hart Publishing 2017).

53 Case C-399/11, Stefano Melloni v Ministerio Fiscal, ECLI:EU:C:2013:107.

54 Case C-341/05, Laval un Partneri Ltd v Svenska Byggnadsarbetareförbundet, Svenska Byggnadsarbetareförbundets avdelning 1, Byggettan and Svenska Elektrikerförbundet, ECLI:EU:C:2007:809; AGET Iraklis (n 42); Case C-426/11, Alemo-Herron, ECLI:EU:C:2013:521. 
The Economic and Monetary Union (EMU) illustrates the weakness of solidarity and its potentially dignity-undermining effects. While the 'bail-outs' involve a significant measure of risk and as such constitute a sub-optimal action for the assisting Member States, and thus the necessary elements of a (weak) action of solidarity are present, there is a profound problem in the concrete way in which conditionality has been given shape. The Memorandums of Understanding have not been drafted in a spirit of transnational solidarity by the creditor states and with due regard to national solidarity structures, but instead carry a punitive flavour and have contributed to a grave social crisis in the debtor countries. ${ }^{55}$ These actions have served to undermine the collective dignity of the debtor states - by undermining their agency as independent democratic states and by protracted public shaming - as well as the dignity of citizens within these states - by exposing them to poverty and social exclusion. All this has gravely damaged the twofold reciprocity-based solidarity fabric of the EU: citizens of debtor states feel like they have been made to sacrifice their social welfare in order to maintain the common economic system from which creditor states benefit all too much, while citizens of the creditor states feel that they have been made to redistribute their hard-earned wealth to debtors who have not duly contributed to the common system that generated that wealth.

More generally speaking, the EU's solidarity mechanisms do not seem a priori conceived as dignity-based, or in any event they cannot successfully combat the sense of indignity that results from a loss of (quality of) employment due to company restructuring, relocation or service provision competition in the internal market. Redistribution of wealth and structural investments are necessary but not sufficient in the face of loss of meaningful and good-quality employment. While of course the EU internal market also creates employment opportunities, and as such there may very well be significant net gains in 'social and employment dignity' thanks to the internal market, this in itself will be meagre consolation to the losers, especially in the face of low levels of transnational solidarity. The increased individual agency and socio-economic opportunity conducive to dignity as created by EU law are real, but are overall most keenly felt by mobile citizens, who remain a minority.

In this, the role of fundamental rights in the EU legal order is ambiguous. There is first the problem of the Charter's non-application in some of the crucial contexts mentioned above, such as the European Stability Mechanism Treaty and the European Semester. And even where we are in the scope of binding EU law, the Charter has up to now failed to lead to the establishment of a thick and balanced constitutionalism at EU level that ensures a mainstreamed commitment to dignity in its physical, democratic and political, and

55 For a comprehensive discussion see Garben ( $\mathrm{n} 41$ ). 
social dimensions ${ }^{56}$ which could lead to a better balance between competition, solidarity and cooperation in the EU legal and political system. The most profound problem in this respect is that, more than most other legal orders, the EU has constitutionalised not only civil, political and social rights but also economic freedoms. The free movement provisions in the context of the internal market, as well as the freedom to conduct a business laid down in the Charter itself, have been given an extraordinarily powerful role in the EU's constitutional configuration, and at times they have had primacy over more traditional fundamental human rights..$^{57}$ The way these norms interact is resolved on an ad hoc basis rather than embedded in a rich theory of dignity and constitutional democracy, ${ }^{58}$ which is emblematic of the vacuous nature of European constitutionalism. ${ }^{59}$

\section{THOUGHTS ON THE WAY FORWARD}

\subsection{The Need for a Dignity-based Solidarity Framework for the Union}

Following Habermas, ${ }^{60}$ the stability of a federal union requires a degree of civil solidarity, which cannot develop if social inequalities between the Member States, or between certain groups of citizens within and between the Member States, become permanent structural features. In the second section of this chapter, we indicated that (i) participation in a common project (such as the $\mathrm{EU}$ as a whole or the internal market more specifically) without a guarantee of immediate net benefits, and (ii) the subsequent redistribution of the yields of that common system from the winners to the losers, are both acts of solidarity. These two acts of reciprocity-based solidarity can furthermore be considered as interrelated. If the same actors (individuals, social groups, Member States) are consistently asked to perform the first act of solidarity, that is, to participate in the scheme without guaranteed benefits, and it consistently turns out that

56 Sacha Garben, 'Balancing social and economic fundamental rights in the EU legal order’ (2020) 11(4) European Labour Law Journal 364.

57 Laval (n 54).

58 Sacha Garben, 'The "Fundamental Freedoms" and (other) fundamental rights: towards an integrated democratic interpretation framework' in Sacha Garben and Inge Govaere (eds), The Internal Market 2.0 (Hart Publishing 2021).

59 Joseph Weiler, The Constitution of Europe: Do the Clothes Have an Emperor and Other Essays on European Integration (CUP 1999); Maria Cahill, 'European integration and European constitutionalism: consonances and dissonances' in Daniel Augenstein (ed), Integration through Law Revisited - The Making of the European Polity (Ashgate 2012).

60 Jürgen Habermas, The Crisis of the European Union: A Response (Polity 2012). 
the benefits that are generated do not fall to them, making them the 'losers' of the system - and if subsequently the 'winners' do not engage in the second act of solidarity, that is, redistribution - then the losing group will at some point refuse to continue engaging in its first act of solidarity. Indeed, in such a situation, the 'losers' are not asked to participate in a common project where the individual yields will be uncertain, but instead in a framework where their personal loss is certain. Such sustained generosity can only be expected when group ties are so strong that the gains of another member of the group are vicariously felt, which is not likely in an EU context. It also works the other way around, as 'winners' are not likely to engage in the second act of redistributive solidarity if the 'losers' are not willing to fully cooperate in the common project that generated the benefits in the first place.

In addition, the foregoing discussion suggests that effective solidarity should be dignity-based, for otherwise it may lead to ineffective or even counter-productive results. On the one hand, this suggests that the decision to participate in the common project should be felt as a deliberate and voluntary one, for otherwise it would undermine an important part of citizens' democratic agency and thereby their collective and individual dignity. On the other hand, this also means that any redistribution of the gains of the project should carefully respect the recipients' dignity. It should not only tangibly benefit the individual directly (instead of only their respective region more generally), but also should not take the form of a benefit that could be felt as charity and rather make a concrete contribution to the individual's meaningful employment or individual agency in a different way. Retraining and lifelong learning are important policies that hold much potential in this regard, but if such policies are not carefully designed from a dignity perspective they may still lack effect or become counter-productive (for instance if the training does not at all correspond to the level and interest of the individual, and/or is compulsory to receive benefits).

\subsection{Tentative Proposals to Enhance Dignity-based Solidarity in EU Law}

What can we make of this for the current EU? It would seem that, in order to ensure its stability and success as a federal system, the EU needs to better institutionalise the above mutually reinforcing two-step solidarity structure, while making it dignity-based. It needs to ensure that (i) everyone deliberately participates in the common project (largely defined) without expecting a guaranteed net benefit in the immediate term, and (ii) that there are sufficiently robust redistributive mechanisms in place so that individuals, groups and Member States that (structurally) lose in the common system are duly compensated in a way that does not undermine their agency and sense of self-worth. 
EU law can play an important instrumental role here. In legal terms, the principle of sincere cooperation as laid down in Article 4(3) TFEU, or the overarching general principle of EU law of inter-Member State solidarity, should be (re-)interpreted to impose some stronger positive duties of cooperation under EU law. Of course, there is a difficult balance between, on the one hand, the political freedom, and thus the agency and dignity, of the Member States to pursue their own interests, which may sometimes be precisely to the detriment of other Member States, and, on the other hand, a duty to cooperate in a spirit of solidarity to find common solutions to problems experienced disproportionally by another Member State. A case could be made that the duty to cooperate should be especially strong when: (i) the problem experienced by the Member State in need is linked to, or the consequence of, common policies, externalities or Europeanisation more generally, thus imparting a certain responsibility on some or all other Member States for the occurrence of this problem; (ii) one or more Member States specifically benefit from the problem experienced by the Member State in need or from not solving it together (free-riding); and (iii) the problem or situation experienced by the Member State in need is objectively considered undesirable, particularly in light of common EU objectives such as high levels of social, health and environmental protection or human rights. In such circumstances, the duty of federal solidarity could imply a strong procedural obligation for the Member States to negotiate in good faith toward a common solution.

We have seen a tentative development in this direction with the legal actions taken by the European Commission in the context of the migration crisis, which the Court has upheld. ${ }^{61}$ The principle could (have) play(ed) a larger role in the context of the EMU, to ensure that any conditionalities that were imposed on debtor states would not hamper the Union's core objectives of Articles 2 and 3 TEU, which include solidarity and human dignity. More generally, the country-specific recommendations issued in the context of European economic governance should be subject to some sort of political or judicial review, to ensure that they respect these same core objectives of Articles 2 and 3 TEU. ${ }^{62}$ It would seem that, precisely, the principle of sincere cooperation lends itself to application to situations that are, formalistically speaking, not binding EU law, but that pertains to the behaviour of EU institutions and Member States more generally.

Second, the EU legal order should be more firmly anchored in the overarching value of human dignity, in all its dimensions (including that of democratic agency). This should be operationalised first and foremost by the development

61 See Bengoetxea, ch 7 in this volume.

62 See also Pieter Pecinovsky, ch 4 in this volume. 
of a thick constitutional democratic theory for the EU, by academia and the CJEU. I have developed that proposal in more detail elsewhere. ${ }^{63}$ Crucially for our purposes, such a framework would imply a less 'fundamental' approach to the internal market freedoms, de-constitutionalising them to a certain extent and thereby leaving more space for democratic decision-making. This should reduce the competitive and de-regulatory forces currently eroding dignity-based solidarity in the internal market, putting less negative pressure on national solidaristic policies, which would only be replaced by European-level standards where these are adopted through 'positive' integration in the form of legislation adopted following the Community Method (as an active expression of transnational cooperation and solidarity).

Finally, the framework developed in this contribution argues against differentiated integration. If a specific group cannot accept a basic dignity- and reciprocity-based solidarity as the basis of the constitutional settlement for the Union, because levels of identification with the overall European community are too low to motivate anything beyond a 'guaranteed net-benefit investment' approach, then it may be better for that group to withdraw from the Union. That outcome is to be preferred over a formula of differentiated integration, allowing states to be (quasi-)members without committing fully to the first (and perhaps second) act of solidarity and instead cherry-picking the parts of the project where immediate net benefits are anticipated or even guaranteed; such an approach will ultimately unravel the very fabric of the Union. The foregoing discussion suggests that a Europe à la carte is not a sustainable federal model and would aggravate Europe's current crises instead of solving them. Indeed, as the tragic Brexit experience shows us, it would seem that a basic commitment to the twofold reciprocity-based solidarity as set out in this chapter is a de facto (and should be a de iure) sine qua non for EU membership. A forceful application of this core criterion may leave us with a smaller group, but one that is founded on the right kind of social contract.

\section{CONCLUSION}

The Union is embarking (yet again) on a process of reflection about its future, which is to be welcomed. It would be fruitful for these discussions to take place along the lines of the desire for a stronger legal obligation on Member States to fully commit to both acts of reciprocity-based solidarity (cooperation and redistribution), and that this should take place in a specifically dignity-oriented way (and what the role of EU fundamental rights could be in that respect). In addition, there is of course an important political side to the implementation

63 Garben (n 56 and n 58). 
of this normative framework for European integration, particularly in terms of how it can be clearly communicated to EU citizens. If the case is coherently made that EU membership implies a degree of reciprocity-based solidarity entailing full participation in the project for the common benefit, in which returns will not necessarily be immediate but eventually will be fairly distributed among all participants - and if the way in which all members participate and contribute, as well as the common benefit in its various manifestations, is clearly identified and communicated - this is highly likely to help convince citizens to support European integration. Effective communication of this message could be expected to boost the sense of agency of the 'winners' and reduce the sense of shame of the 'losers', thus benefiting societal cohesion, equality and dignity. 